\title{
A FEJLŐdÉSI DISZLEXIÁRA (FDL) JELLEMZŐ BESZÉDHANG-FELDOLGOZÁSI ZAVAROK ELTÉRÉSI NEGATIVITÁS (EN) KORRELÁTUMAI
}

\author{
CSÉPE VALÉRIA-SZÜCS DÉNES \\ MTA Pszichológiai Kutatóintézete, Pszichofiziológiai Osztály \\ Fejlődés-pszichofiziológiai Csoport \\ E-mail: csepe@cogpsyphy.hu; sdini@cogpsyphy.hu \\ OSMANNÉ SÁGI JUDIT \\ MTA Pszichológiai Kutatóintézete, Pszichofiziológiai Osztály \\ E-mail: sagi@cogpsyphy.hu
}

\begin{abstract}
A fejlödési diszlexia vagy olvasási zavar a tanulási zavarokon belül elkülönülve kifejezetten az olvasási képességnek többnyire olyan zavarát jelenti, amely egy életen át fennmarad. Az elmúlt évtized kísérletes munkáinak köszönhetöen összegyült adatok egyértelmüen arra utalnak, hogy a fejlödési diszlexiában a látási és hallási feldolgozás egyaránt sérült. Jelen tanulmány célja annak vizsgálata volt, hogy a diszlexiások feldolgozási jellemzói elkülönithetök-e a hasonló életkorú, ám a különbözö típusú beszédhangok diszkriminációjában igen eltérö teljesítményt mutató kontrollszemélyektöl az eseményhez kötött agyi potenciálok eltérési negativitás (EN) komponensének segítségével. A tiszta hangok, magánhangzók,
\end{abstract}

A közölt kísérleti munka jelentős része bemutatásra került a Magyar Pszichológiai Társaság XIV. Nagygyülésén (Budapest) a „Nyelv és beszéd” szimpóziumban. A kutatás az OTKA T 019875, valamint T 033008 számú pályázati támogatásával (témavezető: Csépe Valéria) valósult meg. Az olvasásvizsgálatok módszereinek kialakítása az Európai Unió által támogatott kutatási együttműködés keretében (COST A8) történt.

A diszlexiás csoporttal összehasonlított kontrollcsoport vizsgálataiban a munkacsoport fiatal kutatójaként vett részt Gyurkócza Enikő. A COST A8 nemzetközi kutatási együttműködés keretében kialakított olvasási teszt fejlesztésében Lukács Ágnes egyetemi hallgatóként vett részt (jelenleg PhD ösztöndíjasként dolgozik a Fejlődés-pszichofiziológiai csoportban). A diszlexiateszteket és az intelligenciavizsgálatokat Kucseráné Gráf Rózsa végezte. Valamennyiüknek, továbbá a vizsgálatok előkészítésében közremúködő logopédusoknak és pedagógusoknak köszönettel tartozunk. Köszönetünket fejezzük ki Marosfalvi Katalinnak és Csite Norbertnek a kísérletek lebonyolításában és az adatok feldolgozásában nyújtott segítségükért. 
valamint mássalhangzóval kezdődő szótagok (CV) eltéréseivel kiváltott EN vizsgálatát 9 éves fejlödési diszlexiások csoportjával, valamint két, életkorban illesztett kontrollcsoporttal végeztük el. Az EN alapján kimutatható leglényegesebb eltérés a diszlexiások és a kontrollcsoportok között a mássalhangzók képzés és zöngésség szerinti eltérésének feldolgozásában figyelheto" meg. Ez az eltérés érvényes a kontrolloknak a gyenge beszédhang diszkriminációs teljesítmény alapján elkülönített alcsoportjával történö összehasonlításban is. EN adataink arra utalnak, hogy a fejlödési diszlexia és a fejlödési lemaradás hátterében a beszédhangok reprezentációja eltéröen érintett.

Kulcsszavak: fejlődési diszlexia, megkésett fejlődés, akusztikai és fonetikai feldolgozás, elérési negativitás, eseményhez kötött agyi potenciálok, beszédhang-diszkrimináció

\section{DISZLEXIA ÉS BESZÉDÉSZLELÉS}

Az olvasás elsajátításának súlyos és enyhébb zavarait kutató munkák az elmúlt másfél évtizedben kiemelten foglalkoztak a nyelvi reprezentáció kérdéseivel, az utóbbi néhány évben pedig egyre erőteljesebb figyelem irányul a hallási bemenetnek és a feldolgozó agykérgi területek fejlettségének a nyelvi reprezentációban betöltött szerepére.

A tanulási zavarok és a figyelemzavar különböző formái a leggyakoribb diagnosztikus kategóriákat alkotják az iskoláskorú gyermekek iskolai alulteljesítésének pszichológiai és neuropszichológiai vizsgálataiban. A becslések szerint tanulási és olvasási zavaroktól a kisiskolások mintegy 9-10\%-a, figyelemzavartól hozzávetőleg 5\%-a szenved (TORGESON, 1999). Ezek közül a gyerekek közül meglehetősen sokaknál figyeltek meg akusztikus diszkriminációs problémákat.

A stabil diszkrimináció hiánya különösen kifejezett a beszédhangok egyes csoportjai esetében. Még inkább feltűnő az a tény, hogy a tanulási zavarok egyik jellegzetes csoportjában, a súlyos olvasási zavarokkal társult tanulási zavarban a beszédhangok alapvető akusztikai eltéréseinek feldolgozása sérült (ELLIOTT, HAMMER, SCHOLL, 1989; REED, 1989). Úgy tűnik, hogy ezek az észlelési zavarok a fonológiai feldolgozási problémákkal és a gyenge olvasással mutatnak szoros együttjárást (MCBRIDE-CHANG, 1995; REED, 1989).

A beszédhangok észlelési zavarainak okai mind a mai napig tisztázatlanok, illetve a zavarok eredetére utaló elképzelések sokszor elég ellentmondásosak. A kutatók egy része úgy véli, hogy a nyelvi funkciók és a tanulási képesség zavarainak alapja nem más, mint a hallási ingerek igen finom és gyors változásainak észlelési zavara (TAllal, 1980; Elliott, Hammer, SCHOll, 1989; TAllal, Miller, Bedi, Byma, Wang, Nagarajan, Schreiner, Jenkins, Merzenich, 1996). Ettől eltérően a másik nagy irányzat véleménye az, hogy ezeknek a gyerekeknek az alapvető hallási feldolgozási képességei épek, a tanulási és nyelvi zavarok elsősorban a fonológiai kategóriák határozatlanságára, reprezentációs zavaraira vezethetők vissza (SHARe, 1995; STANOvich, Siegel, 1994; STUdDERT-KenNedy, Mody, 
1995). A zavarok természetének és okainak kutatásában további problémát jelent a vizsgált populáció heterogenitása, ami egyben arra is utal, hogy a beszédhangok észlelési problémái nem egy egységes jelenség megnyilvánulásai. Másként fogalmazva, az észlelési probléma oka feltehetően minden gyereknél más és más.

A hallási észlelés, ezen belül pedig kiemelten a beszédészlelés zavarainak vizsgálatára többféle módszer terjedt el a klinikai gyakorlatban, mindegyik módszer alkalmazása többféle problémát vet fel, ezekre itt nem térünk ki részletesen. A beszédészlelési funkciók és az erre épülő magasabb szintű nyelvi funkciók működési összefüggéseinek vizsgálata az elmúlt évek során az érdeklődés előterébe került. Mint az a legtöbb diszlexiával foglalkozó kutató által elfogadott, a fonémák központi reprezentációja meghatározó funkciót tölthet be a fejlődésben lévő nyelvi rendszer alakulásában. Az élő beszéd hallgatása során a beszédhangok feldolgozása szeriális, ez a feldolgozás gyors, automatikus és nem igényel feltétlenül tudatos hozzáférést. A kevés hibával múködő nyelvi felismerő rendszer egyik alapvető feltétele az anyanyelvre jellemző fonémakészlet stabil reprezentációja. Jóllehet ez a reprezentáció szoros kapcsolatban áll az alapvető akusztikus eltérések diszkriminációs képességével, a beszéd nyelvspecifikus jellemzői, valamint a gyerek saját észlelési tapasztalatai a reprezentációt lényegesen módosíthatják.

A tréning reprezentációt módosító hatásaira utalnak azok az eseményhez kötött agyi potenciálok (EKP) eltérési negativitás (EN) komponensének változására épülő adatok, amelyek a diszkriminációs gyakorlatokat követően a kontrasztok automatikus feldolgozásának javulását mutatták (KRAUS, MCGEE, CARRELL, Sharma, 1995; Tremblay, Kraus, Carrell, McGee, 1997; Tremblay, Kraus, MCGEE, 1998). Nina Kraus és munkacsoportjának vizsgálataira jórészt ugyanaz a megközelítésmód jellemző, amelyet saját vizsgálataink során is szem előtt tartunk, a magatartási és az eseményhez kötött agyi válaszokkal követhető neurofiziológiai eltérések együttes elemzése.

Míg Kraus és munkacsoportjának vizsgálatai a viselkedéses mutatókat a beszédhangok diszkriminációjának pszichofizikai mérésére korlátozzák, saját vizsgálatainkban a nyelvi képességek átfogóbb elemzését alkalmazzuk és vetjük egybe az elektrofiziológiai korrelátumokkal. Bár a két megközelítésmódnak mások a hangsúlyai, a fő cél a tanulási zavarra, esetünkben ennél szűkebben a diszlexiára jellemző eltérések feltérképezése. A beszédhangok reprezentációjában feltételezett zavarok egyértelmủ bizonyításához azonban elkerülhetetlen a normál funkciók tartományának megismerése. Feltétlenül fontos az életkori jellemzőknek, az éréssel összefüggő olyan változásoknak a feltárása, amelyek a zavarokkal, esetünkben diszlexiával együtt járó viselkedéses és agyi aktivitásbeli változások értelmezését befolyásolhatják. Éppen ezért a diszlexiásoknál kapott adatok szinte értelmezhetetlenek olyan meghatározás nélkül, amely egyértelműen leírja a normál és a zavart funkciókra jellemző mutatókat. Ennek szükségszerűsége különösen indokolt a hallási eseményhez kötött agyi potenciálok esetében. Ezen a területen ugyanis csak az 1990-es években indultak meg a kutatások, és mind a mai napig viszonylag kevés normatív adat áll rendelkezésre. 


\section{AZ EN FEJLŐDÉSE ÉS FELDOLGOZÁSI DEFICITTEL ÖSSZEFÜGGŐ VÁLTOZÁSAI}

Az EN olyan hallási eseményhez kötött agyi potenciál (EKP) összetevő, amely egyszerű és összetett hangok, hallási események kicsiny (bár nem kizárólag ilyen) eltéréseivel váltható ki. A beszédészlelés számára megkülönböztethető akusztikai/fonetikai eltérések automatikus detektálását is jelzi az EN, így ezzel információt nyerhetünk a beszédhangok kérgi reprezentációjának állapotára vonatkozóan. Feltételezzük ugyanis, hogy a beszédhangok kontrasztjainak összemérésekor a szenzoros memória tartalmát a fonémák hosszú idejű reprezentációja befolyásolja. Ebben a pontban véleményünk lényegesen eltér Kraus és munkacsoportja véleményétől, akik szerint kizárólag a beszéd akusztikai dimenziói a meghatározóak (Kraus, Koch, McGee, Nicol, Cunnigham, 1999). Ennek ellenére egyetértünk abban, hogy a beszédészlelési képességek vizsgálatára a fonémaeltérésekkel kiváltott EN alkalmas, és hogy az EN skalpeloszlási jellegzetességeit az eltérő ingersajátosságok feldolgozásáért felelős eltérő generátorok határozzák meg (ALHO, Huotilainen, NäÄtänen, 1995; Giard, Perrin, Pernier, Bouchet, 1990; Kraus, McGee, Carrell, King, LitTMan, Nicol, 1994).

Az EN módszerének alkalmazásához a klinikai kutatások egyre nagyobb reményeket füznek, jóllehet a klinikai alkalmazásig még hosszú út vezet. Az EN felhasználása a érés és a fejlődési zavarok követésére komoly és többszörösen megalapozott igényként merül fel. Mindehhez azonban módszertanilag támadhatatlan kísérleti eljárásokra van szükség, olyanokra, amelyek a fejlődésben lévő idegrendszer és képességstruktúra sajátosságait egyaránt figyelembe veszik.

Az EN stabilitására vonatkozóan megoszlanak a vélemények. Egyes adatok szerint az EN kivételes stabilitást mutat, és ennek okaként a szerzők egy része (például: Kraus, KoCH, MCGEe, NicOl, CunNigham, 1999) a feldolgozásban részt vevő azonos kérgi folyamatokat jelöli meg. Mindez a tiszta hangok esetében evidensnek tűnhet, hiszen a hangmagaság-eltérés automatikus feldolgozása újszülötteknél, csecsemőknél és kisiskolásoknál csaknem azonos latenciával mérhető (ALHO, Sainio, Sajaniemi, Reinikainen, NäÄtänen, 1990; Csépe, Dieckman, Hoke, Ross, 1992; CSÉPE, 1995; KurTZBerg, VAughan, KreuZer, Fliegler, 1995; Cheour-Luhtanen, Alho, Kujala, Sainio, Reinikainen, Renlund, Aaltonen, Eerola, Nä̈̈tänen, 1995; Cheour, Alho, Ceponiene, Reinikainen, SAinio, Pohjavuori, Aaltonen, NäÄTÄnen 1998; Kraus, McGee, Carrell, Sharma, MiCCO, NiCOL, 1993).

Más vizsgálatok eredményei viszont arra hívják fel a figyelmet, hogy az EN jellemzői, mint például a feldolgozási idővel korreláló EN latencia, az éréssel változnak, és ezt komolyan figyelembe kell venni a gyerekek klinikai csoportjainak vizsgálatánál (KORPILAHTI, LANG, 1994). Éppen ezért meglepőnek tűnhet Kraus és munkatársainak az a rendkívül következetesen képviselt álláspontja, hogy az EN (kezdő és csúcslatencia, komponens latenciatartománya) szinte változatlan az iskoláskor elérésekor és az iskolai évek során, továbbá ez a stabilitás kiterjed a beszédhangkontrasztok feldolgozására is (KraUs, MCGEe, CARrell, ZECKER, 
Nicol, Koch, 1996; Kraus, Koch, McGee, Nicol, Cunnigham, 1999). A beszédhangok eltérésének automatikus feldolgozását jelző EN stabilitását azokra a vizsgálatokra alapozzák, amelyekben a /da/-/ga/ kontinuumon egyenletes lépésekben az F3 (harmadik formáns) átmenet változtatásával hoztak létre eltérő hangokat. A szintetizált mássalhangzók eltérésének feldolgozása mögött KRAUS és munkatársai $(1996,1999)$ kizárólag akusztikus eltérésfeldolgozást feltételeznek.

KRAUS és munkatársai a beszédhangokkal kiváltott (formáns-átmenet eltérések) EN életkori stabilitásának bizonyítására nagyszabású vizsgálatsorozatot végeztek az elmúlt években (Kraus, Koch, MCGeE, Nicol, CunnighaM, 1999). Az EKP vizsgálatok területén szinte egyedülálló nagy mintaszámmal dolgozva 1346 és 15 év közötti iskolást vizsgáltak. Tanulmányukban a viselkedéses (d') és EN mutatók szoros korrelációját és az EN stabilitását találták. A különbségi küszöb a /da-ga/ kontraszt esetében az életkorral nem változott, ugyanakkor a /ba-wa/ esetében (formánsátmenet idői eltérése) szignifikáns életkorhatást találták. Éppen ezért meglepő, hogy az EN ilyen eltérést nem mutatott, amiből a szerzők azt a következtetést vonták le, hogy az EN hátterében álló ingerfeldolgozási folyamatok 6 éves korra érettek, s ezek 15 éves korig további változást az EN semmilyen mutatójában (amplitúdó, latencia, terület) nem jeleznek. A stabilitás vonatkozik az EN eloszlási szimmetriájára is, mégpedig mindkét beszédkontraszt esetében. Az EN a szerzők vizsgálati adatai szerint a 6-15 éves normál iskolás korosztályban életkorés nemfüggetlen.

Mindez azért is meglepőnek tűnhet, mivel a kevésbé összetett feldolgozást igénylő tiszta hangokkal kiváltott EN is szignifikáns rövidülést mutat - $11 \mathrm{~ms} / \mathrm{év}^{-}$ SHAFER, MORR, KREUZER, KURTZBERG (2000) adatai szerint és csupán az amplitúdó változatlan, legalábbis a vizsgálatban részt vevő 66 gyerek esetében, akiknek életkora 4 és 11 év közötti volt. A felnőtteknél elvezethető EN amplitúdója azonban, mint az valamennyi vizsgálat (CSÉPE, DieCKMAN, HoKe, Ross, 1992; CsÉPE, 1995, Kraus, MCGeE, Sharma, Carrell, Nicol, 1992; Kraus, MCGEe, Carrell, ZECKER, NiCOL, KOCH, 1996) alapján egyértelmű, szignifikánsan eltér a gyerekekétől.

A fentiek alapján nyilvánvaló, hogy az EN módszerét alkalmazó gyermekvizsgálatoknál az érés és fejlődés aspektusai is meghatározóak. Az EN változásában feltételezett faktorok közül azonban mindenképpen megbízható adatokkal kell rendelkeznünk az akusztikai/fonetikai diszkrimináció és reprezentációfejlődéssel összefüggő, valamint a kérgi feldolgozó hálózat éréssel és használattal (fejlődési és fejlesztési tanulás) összefüggő változásaival, amikor valamilyen fejlődési zavar jellemzőit kívánjuk vizsgálni. Ez igaz valamennyi esetben, amikor a kognitív fejlődéspszichofiziológiai módszereket valamilyen alkalmazott kutatási területen alkalmazzuk, legyen szó nyelvi zavarról, figyelemzavarról, tanulási zavarról, diszkalkuliáról, diszlexiáról.

A fonológiai deficit halmozott előfordulása a diszlexiásoknál arra utal, hogy az anyanyelv beszédhangjainak reprezentációja kialakulatlan vagy elmosódott. Változatlanul eldöntetlen, hogy általános akusztikus deficittel vagy fonémaspecifikus feldolgozási deficittel van-e dolgunk. Ennek szisztematikus vizsgálatát tűztük ki célul a kísérletek megkezdésekor. 
Kísérleteinkben az eltérő akusztikus kontrasztokkal kiváltott EKP komponens EN változásait elemeztük. Az EN adatokat magatartási mutatókkal vetettük egybe, továbbá olyan tesztadatokkal, amelyek lehetővé tették a fejlődési mutatók egybevetését és a kísérleti csoportok heterogenitásának minimalizálását. A kísérletek a következő kérdésekre kívántak választ adni:

1. A fejlődési diszlexia együtt járást mutat-e a finom akusztikus eltérések feldolgozásának általános deficitjével, vagy a deficit elsősorban a beszédhangok eltéréseinek automatikus összemérésében érhető tetten?

2. Amennyiben a fonológiai diszlexia a beszédkontrasztok összemérésének zavarával jár együtt, a mássalhangzó és magánhangzó kontrasztok feldolgozási deficitje eltérést mutat-e?

3. A beszédhangok eltéréseinek feldolgozásában feltételezett zavar a diszlexiára specifikus-e, vagy jellemző a beszédkontrasztok diszkriminációjának megkésett fejlődésére, azaz az olvasási zavarral nem kísért gyenge fonémadiszkriminációra is?

4. Az EN együtt járást mutat-e a kontrollált feldolgozást igénylő fonémadiszkriminációs feladatok eredményeivel?

\section{MÓDSZEREK}

\section{Viselkedéses mutatók}

A vizsgálatokban részt vevő valamennyi gyermekről a szülővel (általában az anyával) részletes anamnézist vettünk fel. Valamennyi esetben az első EKP kísérletet megelőzően a laboratóriumunk számára adaptált módosított Annette-teszttel kezességi vizsgálatot végeztünk, továbbá a 200-8000 Hz tartományban szűrő audiométerrel hallásküszöböt mértünk.

Az intelligencia mérése a HAWIK-R teszttel történt.

A fonémadiszkriminációs teljesítmény vizsgálata az eredetileg afáziások fonémadiszkriminációs teljesítményének mérésére kialakított (Osmanné Sági Judit) páros összehasonlítási teszttel történt. A teszt három egységből áll, ezek a képzés helye, továbbá a zöngésség szerint eltérő mássalhangzókból kialakított szótagpárokat, valamint izolált magánhangzók eltérő párjait tartalmazzák. Az ingerpárok elhangzását követően a vizsgálati személynek azonos-különböző ítéletet kell hoznia. Valamennyi pártípusból 5-5 szerepel a tesztben, a válasz értékelése az össz- és résztalálatok (azonos és eltérő) és hibák (téves azonos, téves eltérő) alapján történik. Az elmúlt években az egyes korcsoportokra vonatkozóan kialakítottuk a fonémadiszkriminációs teljesítmény egyes beszédhangeltérésekre vonatkozó normatív átlagait. 
Az olvasás és megértés vizsgálatára kialakított, eredetileg ugyancsak az afázia vizsgálatára (Osmanné Sági Judit) használt szó-kép azonosítási tesztet az 1-4. osztályos gyerekek korcsoportjára mértük be, és adaptáltuk a diszlexiára jellemző olvasási hibák azonosítására. A teszt 50 szóból áll, egy-egy tesztlapon az elolvasandó szónak megfelelő, illetve a szóval más (fonológiai és szemantikai disztraktorok) típusú kapcsolatban lévő további három képet tartalmaz. A teszt a fonológiai eredetű, továbbá a gyakorisági hatáson alapuló olvasási hibák kiszűrésére különösen alkalmas. Valójában a Peabody-Ridge Vocabulary Test egy végiggondolt magyar megfelelője ez.

A vizsgálatokban részt vevő diszlexiások mindegyike logopédiai szakvéleménynyel is rendelkezett, ezeknek a szakvéleményeknek a kialakítása azonban sokféle, a nyelvi képességeket eltérő szinten és eltérő pontossággal mérő eljárásokkal történt. Az olvasási képességek árnyaltabb felmérésére az EU COST A8 munkacsoportjában kialakított teszt magyar változatát használtuk. A teszteredményeket az olvasási zavar szempontjából homogén diszlexia vizsgálati csoportok kialakításához használtuk. A teszt elemei: tőszámnevek (1-10), tartalmas szavak, funkciószavak, értelmetlen szavak (1, 2 és 3 szótag).

\section{EKP VIZSGÁLATOK}

\section{Kisérleti csoportok}

Az EN finom elemzésére kiválasztott FDL csoport összeállításánál a csoport homogenitását tekintettük elsődleges szempontnak. A 9 fő diszlexiásból álló csoport (átlagéletkor: 9,8 \pm 0,2 év, 3. osztály) az olvasási zavart kísérő képességzavarok szempontjából az elsősorban a nyelvi funkciók zavarával jellemezhető diszlexia altípusba sorolható. A diszlexia logopédiai diagnózisát kiegészítő vizsgálatokat saját, az európai gyakorlatban elterjedt tesztek alapján kialakított nyelvi tesztekkel (lásd később) végeztük. Az így kialakított, a fonológiai diszlexia mint jellemző diagnosztikai kategória szerint homogénnek tekinthető FDL csoporthoz nem szerinti megoszlás, életkor, intelligencia (performációs hányados) és olvasástanítási módszer szerint illesztettük a kontrollcsoportot, amely egy négy éves követéses vizsgálatban részt vevők 2. osztályosaiból került ki. A kontrollcsoportból két alcsoportot képeztünk, mégpedig az azonos-különböző ítéleteken alapuló beszédhang diszkriminációs tesztben kapott teljesítmény alapján. Így két, jól (JD) valamint rosszul diszkriminálókból (RD) álló alcsoportot hasonlítottunk össze a diszlexiásokkal. A válaszokat az FDL mintában kapott eredményekkel hasonlítottuk össze. A beszédhang diszkriminációs tesztben mutatott teljesítmény alapján az FDL csoport tagjai nem különböztek egymástól. Az EN válaszokból a JD és RD alcsoportokban képzett átlagokat az FDL csoportátlagokkal hasonlítottuk össze. 


\section{EN PARADIGMÁK}

\section{Ingerek}

Az egyes kísérleti ülésekben sorozatokban adott hangokat alkalmaztunk. Egy-egy kísérlet kilenc ingerlési blokkból épült fel. Minden második, szükség esetén minden egyes blokk között rövid szünetet tartottunk. Az egyes kísérleti blokkokon belül adott, eltérő hangingerek sorozatának szerkezetét az úgynevezett „kakukktojás”- (oddball) paradigma szabályai szerint alakítottuk ki. A „kakukktojás” kísérleti elrendezés azt jelentette, hogy a gyakran adott azonos ingerek sorozatán belül kisebb gyakorisággal eltérő paraméterű ingerek jelentek meg. A kísérleti személyeknek nem kellet figyelmet fordítaniuk a hangingerre, az ingerekkel kapcsolatos feladatuk nem volt, azaz az EN optimális kiváltására alkalmas passzív „kakukktojás"-paradigmát alkalmaztuk. A kísérleti személyek éberségi szintjének fenntartására és figyelemelterelésként hang nélkül videóról lejátszott színes rajzfilmeket alkalmaztunk.

A kísérleti blokkok három ingertípust képviseltek, az egyes blokkokban egyféle ingerkategóriát, tiszta hangokat, magánhangzókat, illetve mássalhangzóval kezdődő szótagokat alkalmaztunk. A gyakori inger, a standard előfordulási gyakorisága $70 \%$, a két ritkábban adott eltérő inger, a deviáns megjelenési valószínűsége a blokkon belül $15-15 \%$ volt. Az egyes blokkokban a hangingerek sorrendje véletlenszerű volt.

A tiszta hang (T) blokkokban a gyakran adott standard inger $1000 \mathrm{~Hz}$ volt, a két deviáns hangmagassága 1050 és $1200 \mathrm{~Hz}$. Az elől képzett, magas magánhangzókból álló kísérleti blokkokban (V) az [e:] hang szolgált standardként, a két deviáns közül az [i:] hang a nyelvállás szerinti eltérésnek, az [ø:] ajakkerekítés, azaz a képzés módja szerinti eltérésnek felel meg. Akusztikailag az [e:] - [i:] eltérése (F1) kisebb, mint az [e:] - [ø:] eltérés (F1 és F2). A mássalhangzóval kezdődő szótagokból álló kísérleti blokk (CV) standard ingere a felpattanó zárhanggal induló [ba:] volt, a deviánsok ettől zöngésség - [pa:] -, illetve a képzés helye szerint tértek el. A zöngés/zöngétlen eltérés a hangképzési időnek (VOT = voice onset time), esetünkben 80 ms-nak felel meg. A képzés helye szerinti eltérés ennél összetettebb akusztikai eltérés, azaz nem csupán idői, hanem frekvencia-összetételnek és időbeli (spektrotemporális) különbségnek felel meg, ez esetünkben az F2 és F3 formánsátmenetek eltérésének.

Az egyes kísérleti ülésekben a három ingertípusba tartozó blokkokat random sorrendben adtuk. A hangingereket TDH 49 típusú fejhallgatón keresztül monaurálisan (jobb oldal) adtuk. A fejhallgató frekvenciaátviteli paraméterei a 200$20000 \mathrm{~Hz}$ sávban optimálisak, a külső zaj csillapítása kb. 45 dB.

Az elektrofiziológiai jelek elvezetése során a kísérleti személyek hangszigetelt és elektromosan árnyékolt szobában foglaltak helyet. 


\section{AZ AGYI BIOELEKTROMOS JELEK ELVEZETÉSE}

$\mathrm{Az}$ agyi bioelektromos jelek elvezetése és feldolgozása valamennyi kísérletben ugyanazon módszerrel történt. Az ingeradás és -vezérlés, valamint a bioelektromos jelek rögzítése IBM kompatíbilis Pentium számítógéppel történt. A hajas fejbőrről elvezetett bioelektromos jelek erősítésére Neuroscan gyártmányú, 32 csatornás Synamp típusú erősítőt használtunk. A mintavételezés a SCAN 3.0 verziójú Neuroscan szoftvercsomag, az ingeradás a STIM 2.0 program alkalmazásával történt.

A bioelektromos jelek elvezetésére a hajas fejbőrre ragasztott elektródákat használtunk. A Medicor ${ }^{\mathrm{III}}$ típusú (átmérő: $9 \mathrm{~mm}$ ) elektródák felhelyezésére kombinált rögzítő és vezető tulajdonságú EC2 típusú elektródapasztát (Grass) használtunk. A vízzel lemosható elektródapaszta klinikailag tesztelt hipoallergén készítmény, emiatt gyermeken végzett vizsgálatokban is biztonsággal alkalmazható. Az elektródák felhelyezése a nemzetközi 10-20 rendszer előírásainak megfelelően történt. Az egyes kísérletekben 16-26 elektródát használtunk. A valamennyi kísérletben azonos elvezetések az Fz, Cz, Pz, F3, F4, C3, C4, T3, T4, T5, T6, P3 és P4 elektródák voltak. A felnőtt kísérletektől eltérően referenciaelektródaként a két összekötött masztoid szolgált. Földként a homlokra ragasztott elektródát használtuk. Az adatfeldolgozás során a szemmozgási műtermék kiiktatását szolgáló horizontális (HEOG) és vertikális szemmozgás (VEOG) követésére a szemzúgok külső oldalán, illetve a jobb szem fölött és alatt elhelyezett elektródok szolgáltak.

A bioelektromos jelek rögzítése folyamatos EEG üzemmódban történt. A mintavételezési frekvencia $250 \mathrm{~Hz}$, a szűrési tartomány 0,1-70 Hz volt.

\section{ADATFELDOLGOZÁS, STATISZTIKAI ELEMZÉS}

A számítógépen rögzített jelek feldolgozását a kísérleteket követően (off-line) a Neuroscan szoftvercsomag feldolgozó alprogramjának segítségével, valamint az intézeti fejlesztésben kialakított ERP2.2. program felhasználásával végeztük. Az egységes EEG regisztrátum triggerhez (= eseményhez) kötött szakaszolása azonos idői ablak alkalmazásával történt. Az ingert megelőző (prestimulus) 50 ms-os tartomány átlagolt értéke az alapszintet (biológiai alapvonal) határozta meg. Az inger előtti 50 ms-ból és az inger utáni 400 ms-ból álló egységeket (epoch) szelektíven átlagoltuk. Az átlagolás során a szemmozgás, izomfeszülés vagy mozgás következtében műterméket tartalmazó egységeket az átlagolásból kihagytuk (számítógépes programmal végzett műtermékszűrés). A nyers válaszok átlagolása során alkalmazott utólagos szürés az 1-30 Hz tartományban történt.

Ingertípusonként külön átlagoltuk a standard, valamint a kétféle deviáns ingerrel kiváltott válaszokat. Az EN könnyebb tanulmányozást szolgáló eljárásnak megfelelően mindhárom ingertípus esetében a deviáns ingerrel kiváltott átlagolt válaszból (Dev) kivontuk a standarddal kiváltott átlagolt választ (Std). Az EN paramétereit (csúcsamplitúdó és csúcslatencia) az így keletkezett különbségi görbéken (Dif) mértük. 
Az EN paraméterek statisztikai elemzését a STATISTICA 6. számítógépes statisztikai program felhasználásával végeztük. Az adatok statisztikai elemzésénél többszempontos varianciaanalízist alkalmaztunk.

\section{EREDMÉNYEK}

Az 1., 2. és 3. ábra a CV, az 4. és 5. ábra a magánhangzó, a 6. és 7. ábra a tiszta hang paradigmában elvezetett EN alcsoport átlagainak változásait mutatja be.

Amint az az 1. ábrán jól látható, az FDL csoport különbséggörbéin a képzés helye szerinti kontraszttal kiváltott EN teljesen hiányzik. A 200-250 ms latenciatartományban várható negatív komponens helyét széles, frontális maximumú pozitivitás foglalja el. Bár a kontrollcsoport különbséggörbéin is megfigyelhető egy nagy pozitív hullám, ezt azonban mindkét alcsoport válaszain az EN előzi meg. Jól látható különbség a JD és RD csoport átlagai (JDACA és RDACA) között az EN eltérő nagysága és megoszlása. A JD csoportban az EN csúcsamplitúdója az RD csoporténak mintegy kétszerese, továbbá a JD csoport EN eloszlását a bal centrális és centrális maximum jellemzi. Az RD csoport EN eloszlására inkább a viszonylagos szimmetria jellemző.

A 2. ábrán bemutatott, a zöngésség szerinti eltéréssel kiváltott válaszok jellemző eltérései tendenciájukban a képzés helye szerinti eltéréssel kiváltott EN válaszokéhoz hasonlóak. Az FDL csoport válaszainak jellemző eltérése azonban, hogy az EN, jóllehet igen kis amplitúdóval, megjelenik. A válaszok szembetűnő furcsasága az EN relatív nagysága a C3 elvezetésben, továbbá a kifejezett, nagy amplitúdójú pozitivitás jelenléte valamennyi elvezetésben. A kontrollcsoportot változatlanul a nagy amplitúdójú, bal centrális maximumú EN jellemzi a JD alcsoportban (JDACA), valamint a kisebb amplitúdójú, szimmetrikus EN az RD csoportban (RDACA). Az EN-t követő pozitivitás mindkét csoportban valamennyi válaszon megfigyelhető.

A 3. ábra grafikonjai az FDL, JD és RD alcsoportokban a képzés és zöngésség szerinti beszédhangkontraszttal kiváltott EN amplitúdó- és latenciaértékeinek átlagait tűntetik fel. A képzés (GA) kontraszt esetében az FDL csoportban elvezetett EN amplitúdója mind az RD, mind a JD csoporttal való összehasonlításban szignifikánsan kisebb $\left(\mathrm{F}_{2,21}=3,928, \mathrm{p}<0,05\right)$, továbbá csúcslatenciája szignifikánsan hosszabb $\left(\mathrm{F}_{2,21}=3,645, \mathrm{p}<0,05\right)$. A zöngésség kontraszt $(\mathrm{PA})$ esetében az EN amplitúdó eltérése szignifikáns az JD-FDL $\left(\mathrm{F}_{2,21}=4,004, \mathrm{p}<0,05\right)$ és RD-FDL $\left(\mathrm{F}_{2,21}=3,541, \mathrm{p}<0,02\right)$ összehasonlításban. Ebben a paraméterben a JD és RD csoportokban elvezetett EN válaszok statisztikailag lényeges eltérést nem mutatnak. Ugyanez vonatkozik az EN csúcslatencia szerinti eltérésekre is. 
Fonémaeltéréssel kiváltott EN

Kontraszt: képzés helye

FDL
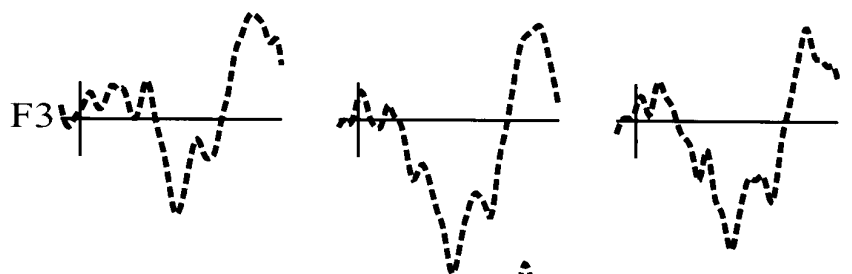

JDACA
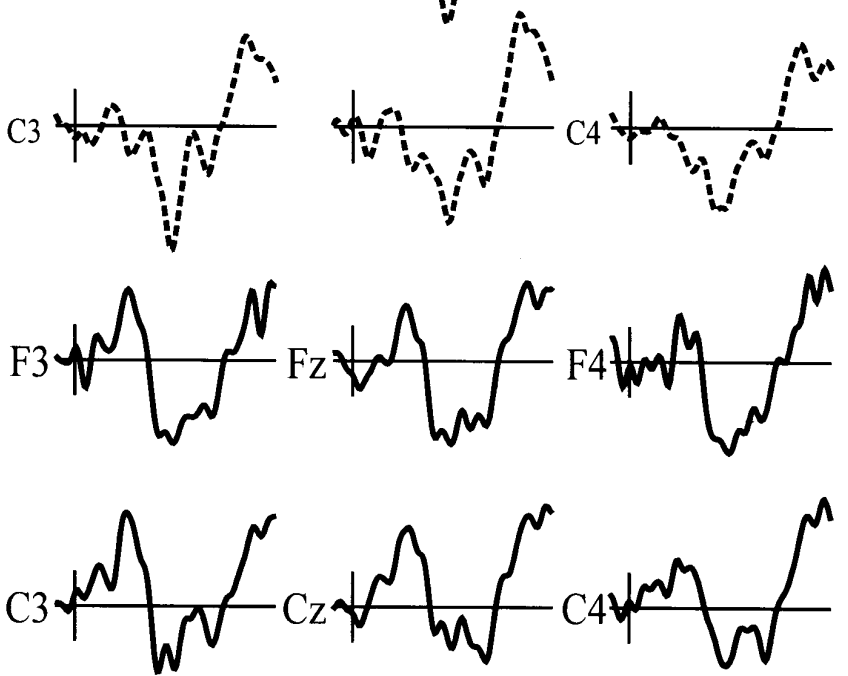

RDACA
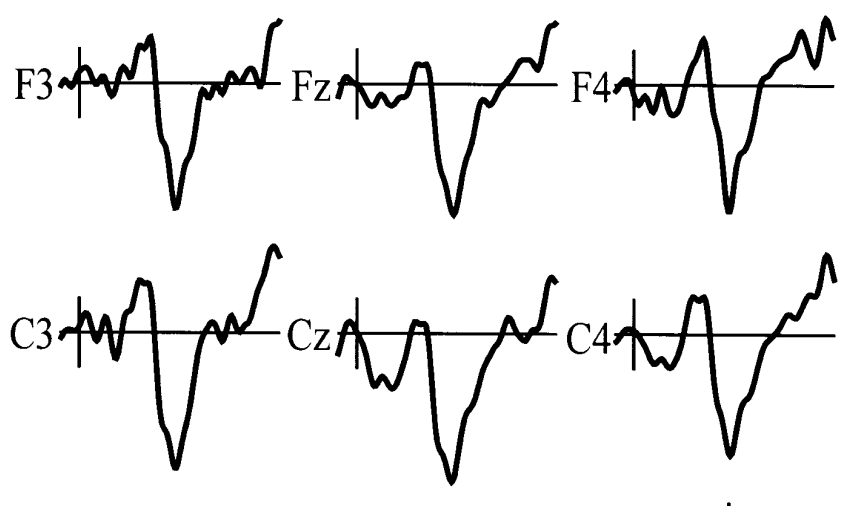

$-2 \mu \mathrm{V} \lcm{100 \mathrm{~ms}}$

1. ábra. Mássalhangzók képzés helye szerinti eltérésével kiváltott EN alakulása a fejlődési diszlexiával (FDL) diagnosztizált csoportban, valamint az illesztett kontrollcsoport jó (JDACA) és rossz (RDACA) beszédhang diszkriminációs teljesítményt mutató csoportjaiban.

Az EKP-ok negatív polaritása az ábrán és a további ábrákon felfelé mutat 
Fonémaeltéréssel kiváltott EN
Kontraszt: zöngésség

FDL

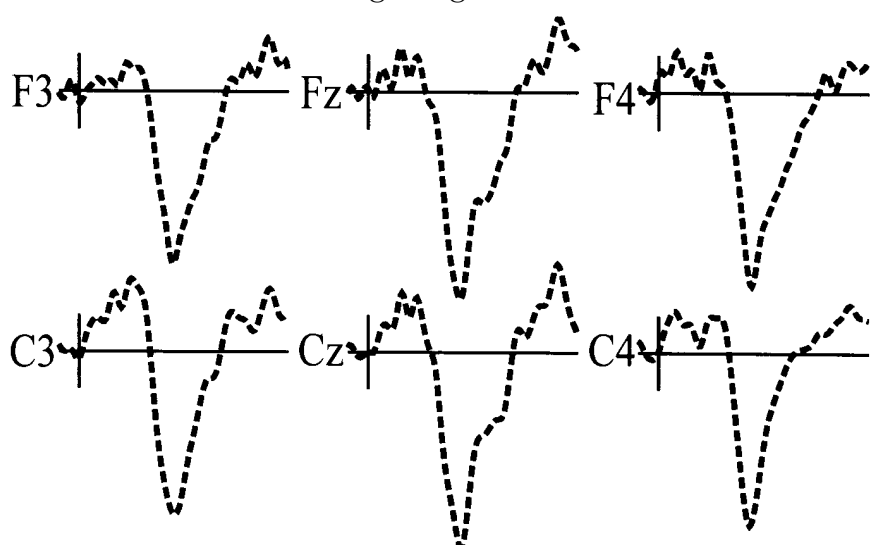

JDACA

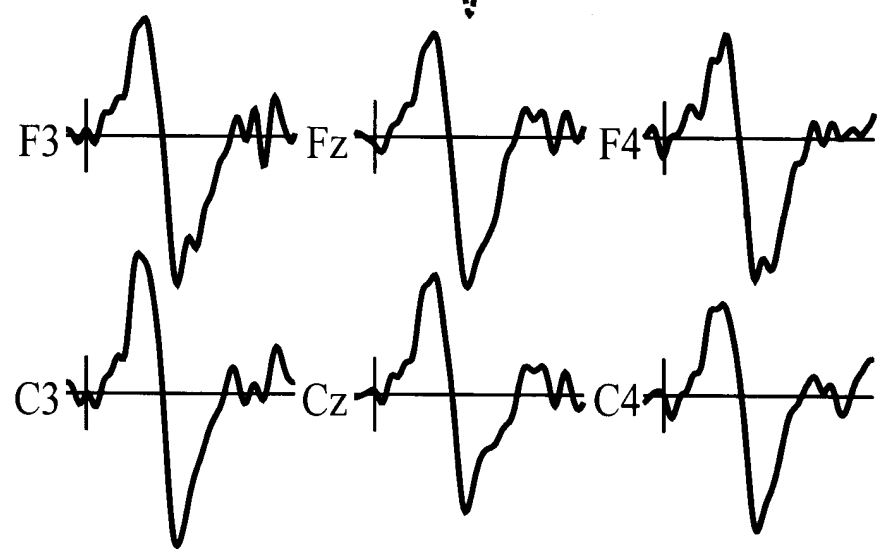

RDACA
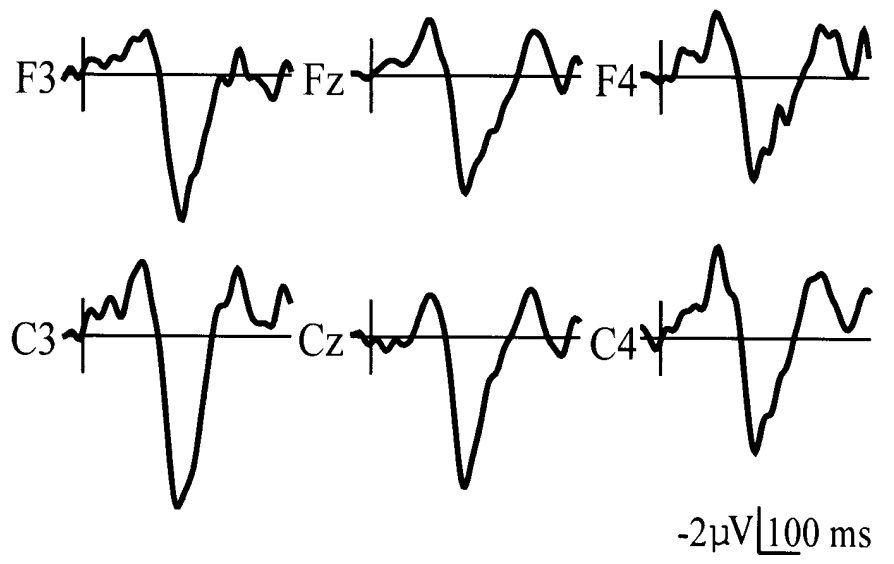

2. ábra. Mássalhangzók képzés helye szerinti eltérésével kiváltott EN alakulása. A jelölések azonosak az 1. ábráéval 
Fonéma-EN

átlag csúcsamplitúdók és -latenciák
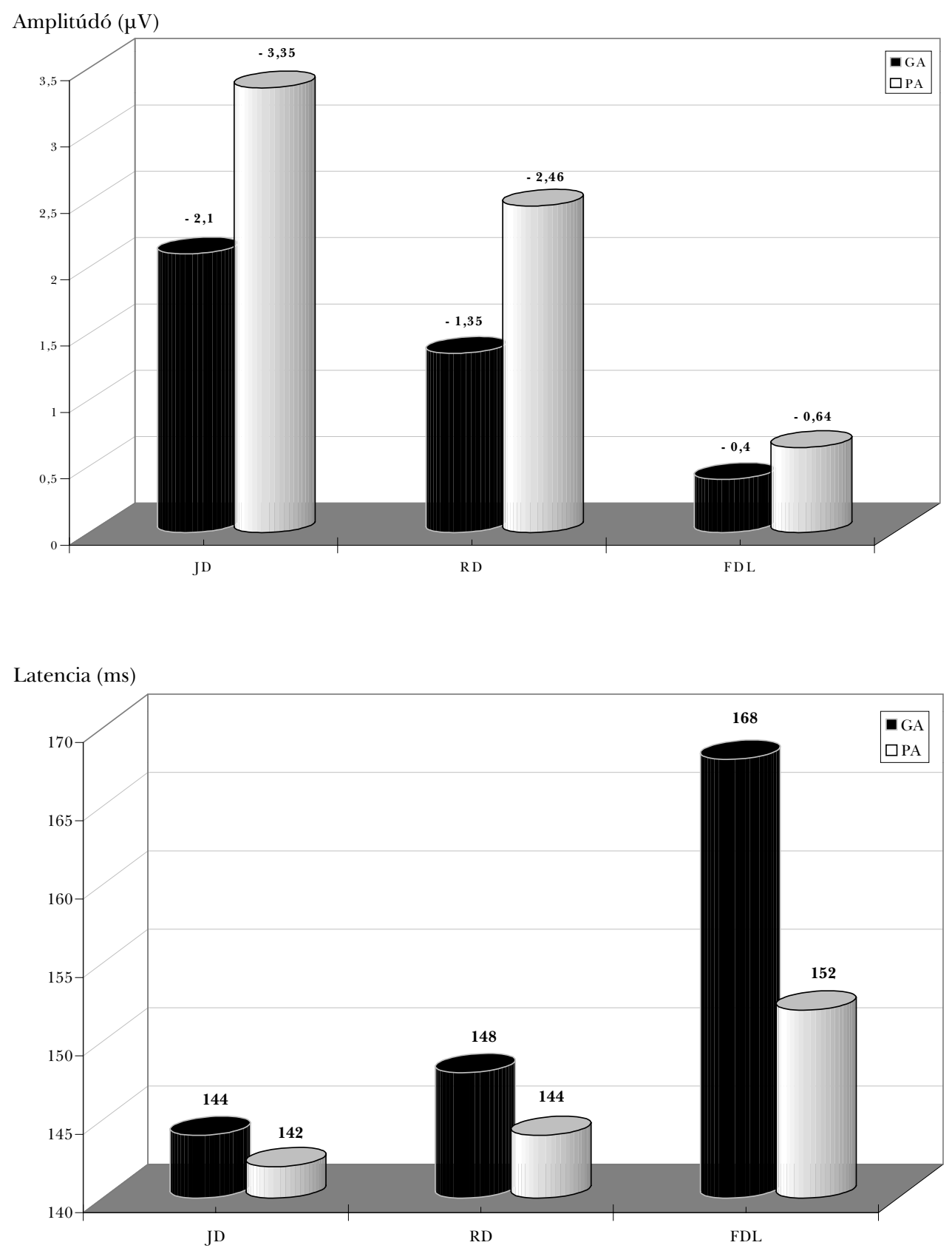

3. ábra. A mássalhangzók eltérésével kiváltott EN csúcsamplitúdó és latenciaértékeinek eltérése 
A 4. ábra a magánhangzó paradigmában kis eltéréssel (nyelvállás) kiváltott EN jellemző változásait mutatja be. A FDL csoport válaszaira jellemző a kis amplitúdójú EN. Az EN eloszlását a centrális maximum és a szimmetria jellemzi. Feltűnő jellegzetessége a FDL csoport különbséggörbéinek egy második negativitás megjelenése a 400 ms körüli latenciatartományban. A JD csoportban elvezethető EN a csoportátlagokon (JDACA) nagy amplitúdójú és bal frontocentrális maximumú. A C3 maximum az RD csoportra is jellemző.

A nagyobb akusztikai eltérésnek megfelelő magánhangzó kontraszt (kategória) esetében (5. ábra) az EN az FDL csoportban is valamennyi elvezetésben jelen van, a második negativitás azonban továbbra is az FDL csoport jellegzetes hullámöszszetevője. A statisztikai elemzés eredményei szerint az FDL csoport egyetlen jellemzőben tér el a JD és RD csoporttól, ez pedig a kis eltéréssel kiváltott EN amplitúdója, jóllehet ez az eltérés csak tendenciaszerű, tehát statisztikailag nem szignifikáns.

A 6. ábra a tiszta hangok (T) kis eltérésével kiváltott EN jellegzetes változásait mutatja be. Az FDL válaszokon az EN a legtöbb elvezetésben hiányzik, illetve az F3 és C3 elvezetésben igen kis amplitúdóval jelenik meg. A JD csoport elvezetéseit (JDACA) olyan nagy amplitúdójú EN jellemzi, amelynek jellegzetessége a frontális maximum és a jobb oldali aszimmetria. Lényeges eltérése ezzel szemben az RD csoport válaszainak a kis amplitúdó és az EN szimmetria. A nagyobb eltéréssel (standard 20\%-a) kiváltott EN (7. ábra) jellegzetesen ugyanezt a képet mutatja, bár az EN az FDL csoportban is valamennyi elvezetésben regisztrálható. Jellegzetessége továbbá a válaszoknak a nagy amplitúdójú pozitivitás (P3a).

A T paradigmában a kis különbséggel kiváltott EN amplitúdójában lényeges eltérést mutat a JD csoporthoz viszonyítva $\left(\mathrm{F}_{2,21}=6.541, \mathrm{p}<0.001\right)$, az $\mathrm{RD}$-vel való összehasonlításban viszont nem. Bár a nagyobb eltérés esetében a JD csoport EN amplitúdói nagyobbak, mint az RD és FDL csoportban, ez az eltérés statisztikailag nem szignifikáns. AZ EN latenciák egyik kontraszt esetében sem különböznek lényegesen az egyes alcsoportok között.

\section{A VISELKEDÉSES MUTATÓK ÉS AZ EN}

Az FDL csoportot a beszédhang diszkriminációs tesztben nyújtott alacsony találati arány $(64 \pm 15 \%)$, a téves válaszokon belül pedig a téves azonos válaszok magas aránya $(21 \pm 10 \%)$ jellemezte. A szó-kép azonosítási tesztben a hibák százaléka a kontroll 1-2\%-ához képest 42\%. A hibák fonológiai természetűek, illetve gyakorisági hatásra visszavezethető olvasási hibák voltak.

A finomabb elemzést lehetővé tevő olvasási tesztben a hibák száma különösen magas volt a több szótagú ritka szavaknál, illetve az értelmetlen szavaknál. Az olvasási sebesség csökkenése különösen az értelmetlen szavakra és a funkciószavakra volt jellemző. A fonológiai hibák szignifikáns korrelációt $(\mathrm{r}=0,69, \mathrm{p}<0,01)$ mutattak a fonéma-EN hiányával. 
Tiszta hanggal kiváltott EN

Kontraszt: kis eltérés

FDL

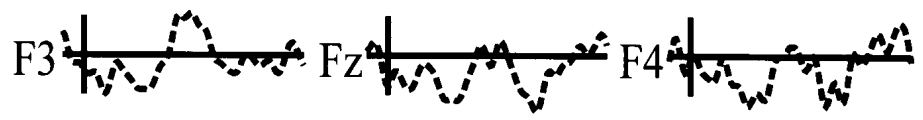

JDACA

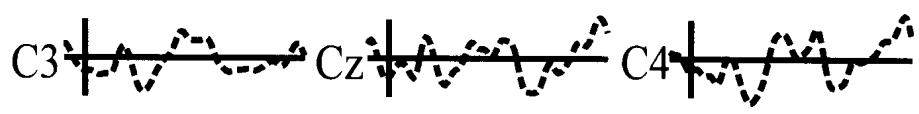

RDACA

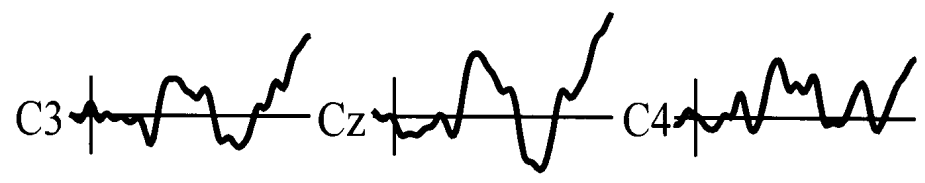

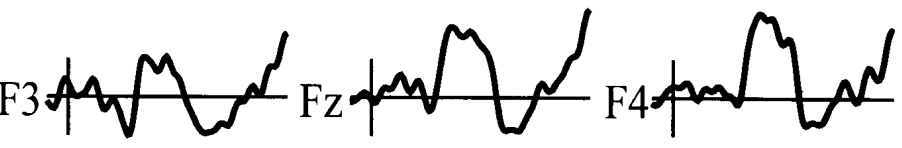

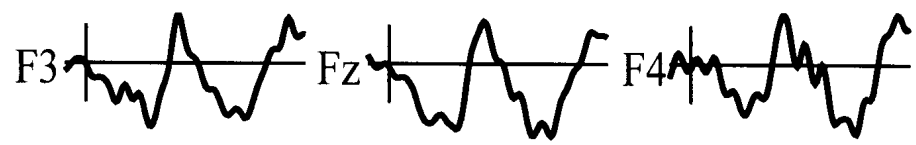

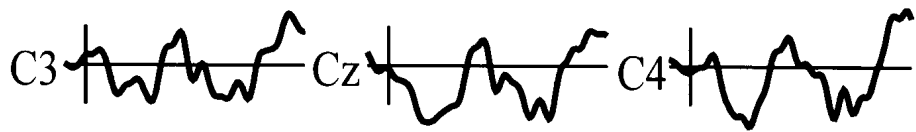

$-2 \mu \mathrm{V} \lcm{100} \mathrm{~ms}$

4. ábra. Tiszta hangok kis eltérésével kiváltott EN válaszok.

A jelölések azonosak a korábbi ábrákéval 
Tiszta hanggal kiváltott EN

Kontraszt: nagy eltérés

FDL
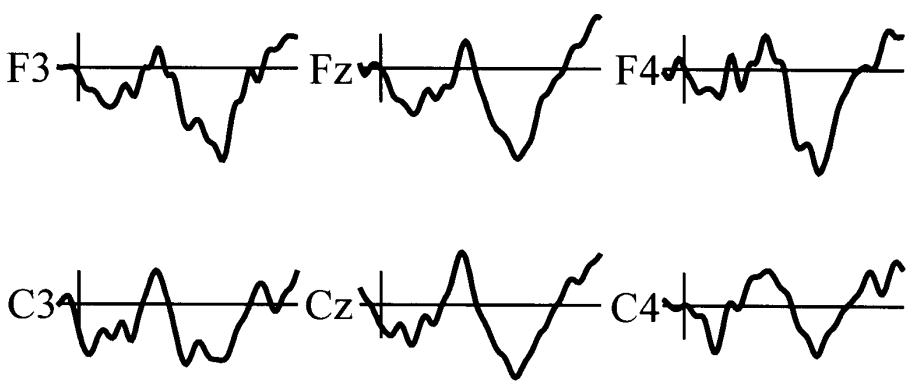

JDACA
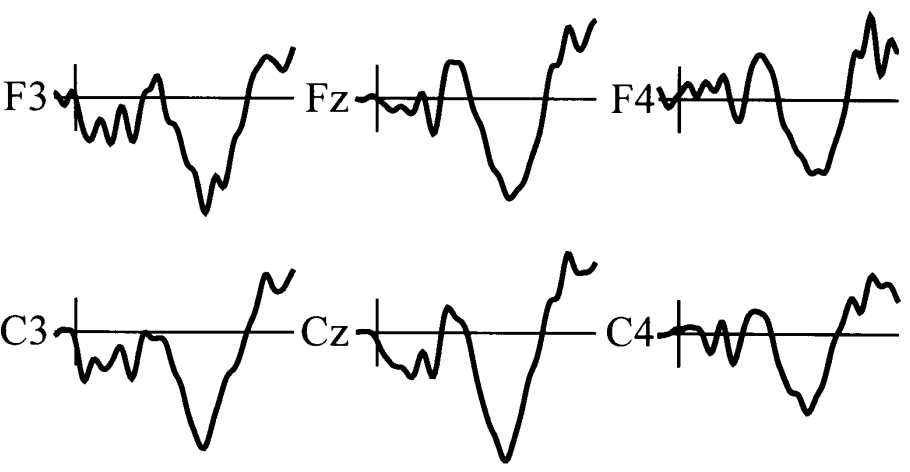

RDACA
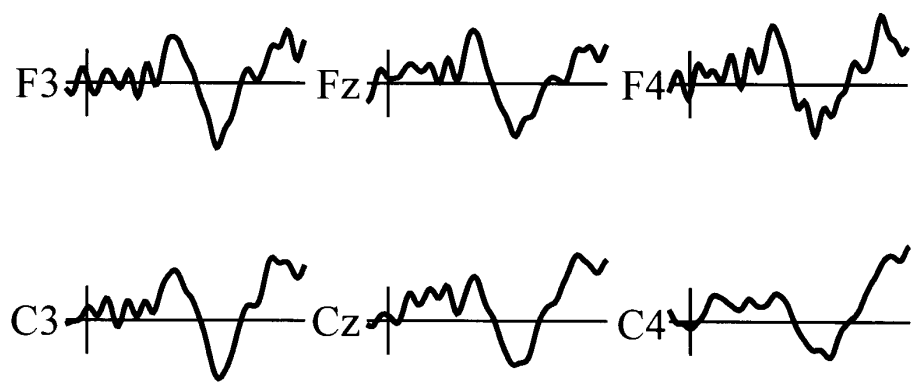
Magánhangzókkal kiváltott EN Kontraszt: nyelvállás

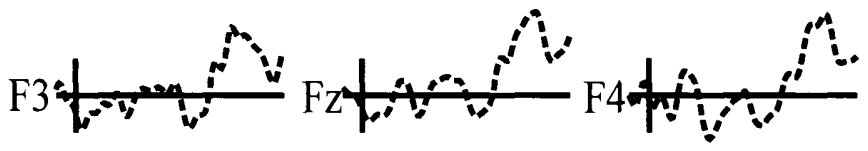

FDL

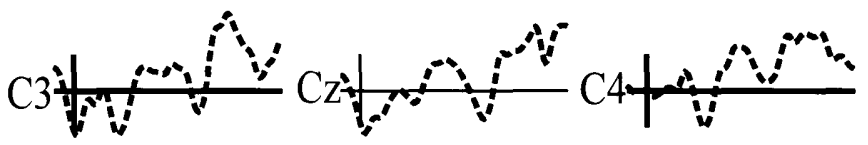

JDACA

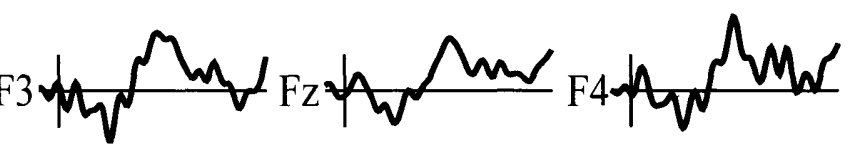

RDACA
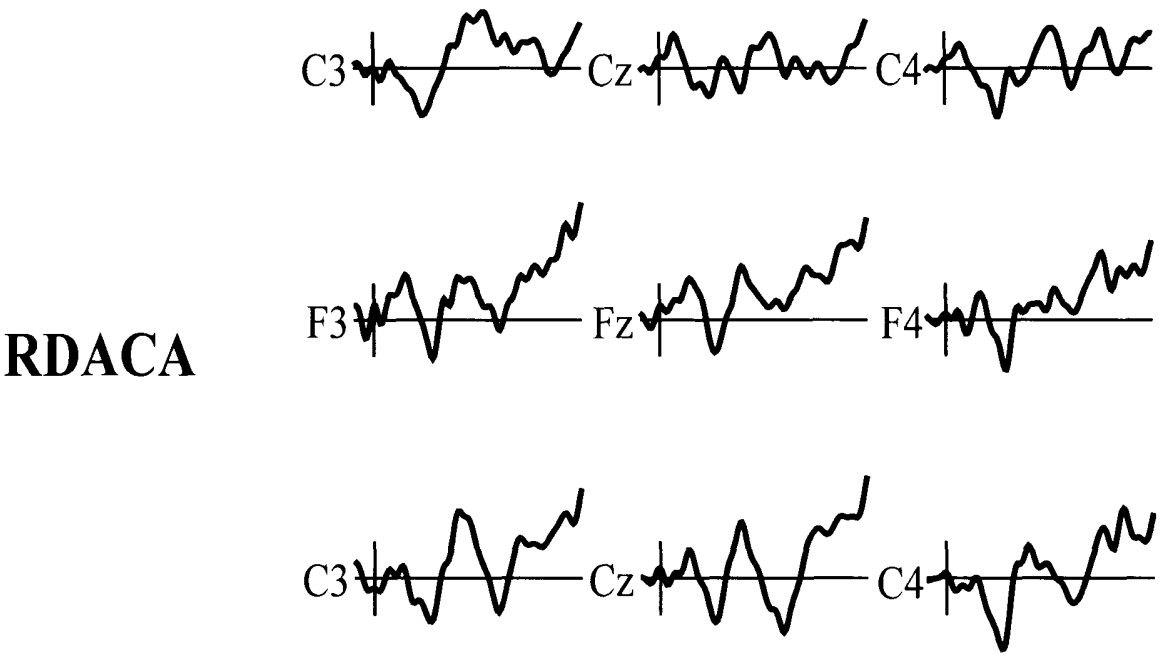

$-2 \mu \mathrm{V} \lcm{100} \mathrm{~ms}$

6. ábra. Magánhangzók kis eltérésével (nyelvállás) kiváltott EN válaszok. A jelölések azonosak a korábbi ábrákéval 


\section{FDL}

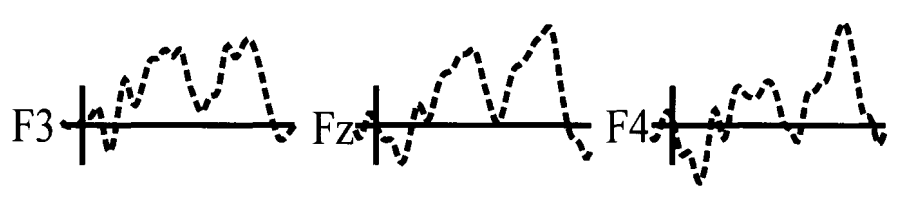

JDACA

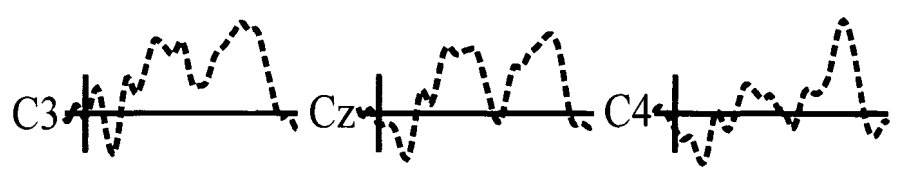

RDACA
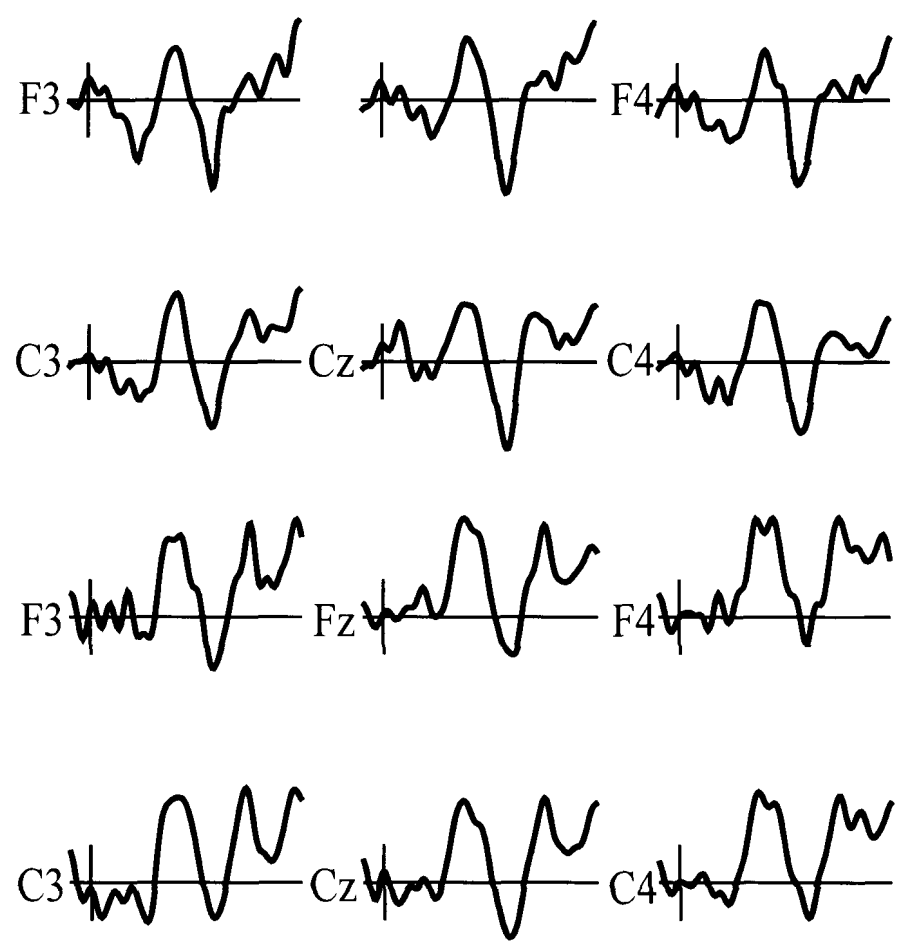

$-2 \mu \mathrm{V} \lcm{100} \mathrm{~ms}$

7. ábra. Magánhangzók nagy eltérésével (kategória) kiváltott EN válaszok. A jelölések azonosak a korábbi ábrákéval 


\section{ÖSSZEFOGLALÁS ÉS MEGBESZÉLÉS}

EKP vizsgálatainkat olyan gyerekek gondosan válogatott csoportjával végeztük, akiknek olvasási zavara mindig a legnagyobb rejtvényt jelenti a szakemberek számára. Ezeknek a gyerekeknek ugyanis sem értelmi képességei, sem egyéb általános képességei nem jelezték előre, hogy az iskolában majd az olvasás és írás elsajátításakor súlyos problémákkal fognak megküzdeni. Ezeket a gyerekeket neveztük jobb híján, keresve de nem találva bizonyossággal megfogható okokat, „valódi diszlexiásoknak", elfogadottabb megfogalmazásban fejlődési diszlexiásoknak.

Az eltérő EN típusok elemzése alapján megállapítható, hogy a fejlődési diszlexiások csoportja komoly deficitet mutat a beszédhangok eltéréseinek automatikus feldolgozásában. Különösen sérülékeny kontrasztnak bizonyult a képzés helye, valamint a zöngésség szerinti kontraszt feldolgozása. Mindezek alapján úgy véljük, hogy a fejlődési diszlexiára sokkal inkább a fonémareprezentáció zavarai jellemzőek, mint a hallási észlelés általános deficitje.

Saját eredményeink és az EN irodalom adatai (STEIN, KraUS, MCGEE, KoCH, 1995) arra utalnak, hogy az úgynevezett fonéma-EN, eltérően a tiszta hangok sorozatával kiváltott EN-től, nem az éppen kialakított szenzoros emlékezeti nyomra támaszkodik, hanem a hosszú távú reprezentációra. Erre utalnak azok az adatok is, amelyek szerint a fonémakontrasztok feldolgozási helye eltér a tiszta hangokétól (Aaltonen, TuOMAInen, Laine, Niemi, 1993; CséPE, OSMAN-SÁGi, MOLNÁR, 1998).

EN adataink összhangban vannak azokkal a közelmúltban publikált, német anyanyelvű diszlexiásokon kapott EN eredményekkel (SCHULTE-KÖRNE, DEIMEL, BATTLING, REMSCHMIDT, 1998), amelyek szerint a diszlexiásokra leginkább jellemző feldolgozási deficit a mássalhangzók kategoriális eltéréseinek detektálásában nyilvánul meg. Saját adataink - azaz a tiszta hangok kis eltérésében ugyan meglévő, de nem csak a diszlexiásokra jellemző feldolgozási deficitje - alapján sokkal inkább elfogadhatónak tartjuk STUDDERT-KENNEDY és MODY (1995) érvelését a feldolgozási deficit nyelvspecifikusságára vonatkozóan, mint az általános, mindenfajta gyors és finom akusztikus eltérésre vonatkozó feldolgozási deficit mellett érvelők álláspontját (STEIn, McANAlly, 1995; TALLAL, Miller, Fitch, 1993).

Ez persze nem azt jelenti, hogy a megfelelő fonémareprezentáció zavarainak kialakulásában nem lehet szerepe a finom akusztikus eltérések feldolgozási deficitjének. Amit állítunk több éves EN vizsgálataink alapján, az ennél árnyaltabb. Úgy véljük, hogy a komplex feldolgozást igénylő fonémakontrasztok, tehát egyes mássalhangzótípusok feldolgozási deficitje a diszlexiások mintegy 70-80\%-ára jellemző, ennél kevesebbre a magánhangzó-eltérések feldolgozási deficitje és még kevesebbre a tiszta hangok gyors változásainak feldolgozási zavara. Azaz nem csupán az akusztikai, hanem a fonetikai feldolgozási sajátosságok is fontosak, sőt ez utóbbiak zavara önállóan is előfordulhat, mint azt saját fejlődési diszlexiásokra vonatkozó adataink is mutatják. Elképzelhető, hogy a finom hallási kontrasztok feldolgozási deficitje elkent, rosszul meghatározott reprezentációhoz vezet, és ez a 7 és 10 éves kor között újabb átrendeződést (ELLIOTT, 1986) mutató kategoriális 
reprezentáció a prototípusok zárása után már nem csupán bizonytalan, hanem kifejezett akadálya a fonológiai lexikon megfelelő használatának.

KERSCHNER és MiCALEFF (1992) szerint a leggyakrabban előforduló diszlexiatípussal, a diszfonémikus diszlexiával diagnosztizált gyerekek a beszédhangok feldolgozásban komoly deficitet mutatnak, továbbá dichotikus hallgatási helyzetben a szokásos jobb fül fölény helyett bal fül fölényt mutatnak. A lateralitás adatokkal és az olvasási teljesítménnyel egybevetve a fonéma diszkriminációs adatokat, a szerzők megerősítettnek vélik azt az agykutatási adatokkal is megerősített feltevést, miszerint a diszlexia leginkább a nyelvi feldolgozó rendszer inverz lateralizációjával jár együtt és ez az inverz lateralizáció környezeti okokkal is magyarázható lehet. Az elsősorban viselkedéses mutatókkal nyert eredményekre támaszkodó szerzők azonban óvatosan nyilatkoznak arról, hogy a gyenge vagy inverz lateralizáció milyen esetekben tekinthető primér, korrelatív vagy másodlagos deficitnek. Mindenesetre arra vonatkozóan vannak adatok, hogy a lateralizáció már a harmadik trimeszterben kialakul (CHI, DoOLING, GILles, 1977; CREUTZFELDT, OJEMANN, LETTICH, 1989), ennek anomáliái a rizikócsoportokban EKP-kal már csecsemőkorban is kimutathatók (LEPPÄNEN, LYYTINEN, 1997; Molfese, 1978; 1980; MolfeSe, Schmidt, 1983; MOlfese, LinnVille, Wetzel, LEICHT, 1985).

Saját vizsgálati eredményeink egybecsengenek a fenti lateralizációs adatokkal. Azoknak a kontrasztoknak az esetében ugyanis, amelyekkel EN-t sikerült kiváltani, a korcsoportra jellemző eloszláshoz képest gyenge vagy inverz lateralizációra utalt az EN skalpeloszlása. Ez eltér a kontrollként alkalmazott gyengén diszkriminálók csoportjától, akiknél inverz lateralizációt nem találtunk, csupán enyhén eltérő, feltehetően későn kialakuló, funkcionális aszimmetriát. Adataink szerint a fonémakontrasztokkal kiváltott EN, különösen pedig a spektrotemporális eltérést reprezentáló képzés helye szerinti EN differenciálisan érzékeny mutatója a diszlexiára jellemző reprezentációs zavarnak.

Jóllehet az exogén komponensek megkésett fejlődésére utaló adatokat magunk is találtunk a diszlexiás mintában, úgy véljük, hogy érdemes fenntartással kezelnünk azokat az irodalmi adatokat, amelyek szerint a P100, N100, P200 komponensek normáltól eltérő eloszlása a diszlexiások jellemzője lenne (PINKERTON, Watson, McClelland, 1989; WoOd, Flowers, Buchsbaum, Tallal, 1991). BRUNSWICK és RIPPON (1994) adatai szerint a beszédhangok feldolgozásának deficitjére utal az exogén válaszok szimmetriája. Adataink szerint ez a szimmetria 8-9 éves korig a kontrollcsoport EKP-komponenseinek is jellemzője, továbbá még nem teljesen tisztázott, hogy az N250 komponens helyén kialakuló két összetevő, Sharma, Kraus, MCGEe és NicOl (1997) szerint N100a és N100b, hogyan változik a jól és rosszul olvasó gyerekek egyes életkori csoportjaiban. 


\section{KITEKINTÉS}

Az utóbbi években egyre több olyan EN adat kerül publikálásra, amely azt mutatja, hogy ez a komponens érzékenysége és alkalmazási feltételei (passzív helyzet, viszonylagos figyelemfüggetlenség, minimális együttmüködési igény) miatt a klinikai gyakorlatban is érdeklődésre számíthat (részletesebben lásd CséPE és MolNÁR, 1997). Az EN valódi klinikai alkalmazásához felnőtteken is még sok mindent kell tisztázni az EN-típusok megbízhatóságával, reprodukálhatóságával kapcsolatban. Ez fokozottan igaz a gyerekvizsgálatokra, amelyekben az érés, fejlődés, tanulás hatásait, valamint ezek zavarait együtt kell kezelni.

A diszlexiával foglalkozó számos tudományterület egyre inkább komplex megközelítésmódot alkalmaz, amelyben a nyelvi funkciók fejlődése, a beszélt és írott nyelv sajátosságai legalább olyan fontosak, mint az agyi struktúra és funkció fejlődésének jellemzői. Már a fonémareprezentáció és a diszlexia összefüggéseinél is utaltunk a nyelvek ortográfiai mélységének vagy más néven a transzparenciának a fontosságára. A nyelvi reprezentáció deficitje ugyanis másként és más szakaszban fontos az olvasás és helyesírás elsajátításakor a különböző nyelvekben. Saját vizsgálataink, illetve valamennyi nem angol európai nyelvről közölt adatok alapján úgy tűnik, hogy a diszlexia mutatói a transzparens nyelvekben mások, a metalingvisztikai képességeknek nem ugyanazok a szintjei fontosak az olvasás elsajátításában, mint az angolban. A nemzetközi szakmai köztudatban az angol olvasási modellek az uralkodóak, ezek azonban nem igazán működnek a transzparens nyelvek esetében. Bár az egységes, valamennyi alfabetikus nyelvre érvényes olvasási modell még várat magára, az angol nyelvből kiinduló olvasási modellek hegemóniája megszűnőben van.

\section{IRODALOM}

Aaltonen, O., Tuomainen, J., Laine, M., Niemi, P. (1993) Cortical differences in tonal versus vowel processing as revealed by an ERP component called mismatch negativity (MMN). Brain and Language, 2, 139-152.

AlHo, K. (1995) Cerebral generators of mismatch negativity (MMN) and its magnetic counterpart (MMNm) elicited by sound changes. Ear and Hearing, 16, 38-51.

Alho, K., Huotilainen, M., NäÄtÄnen, R. (1995) Are memory traces for simple and complex sounds located in different regions of auditory cortex? Recent MEG studies. Journal of Electroencephalography and Clinical Neurophysiology, 44, 197-203.

Alho, K., Sainio, K., Sajaniemi, N., Reinikainen, K., NäÄtÄnen, R. (1990) Event-related brain potentials of human newborns to pitch change of an acoustic stimulus. Journal of Electroencephalography and Clinical Neurophysiology, 77, 151-155.

Bruck, M., Treiman, R. (1990) Phonological awareness and spelling in normal children and dyslexics: The case of initial consonant clusters. Journal of Experimental Child Psychology, 50, 156-178. 
Brunswick, N., Rippon, G. (1994) Auditory event-related potentials. Dichotic listening performance and handedness as indices of lateralization in dyslexic and normal readers. International Journal of Psychophysiology, 18, 265-275.

Ceponiene, R., Service, E., Kurjenluoma, S., Cheour, M., NäÄtänen, R. (1999) Children's performance on pseudo word repetition depends on auditory trace qualityevidence from event-related potentials. Developmental Psychology, 3, 709-720.

Cheour, M., Alho, K., Ceponiene, R., Reinikainen, K., Sainio, K., Pohjavuori, M., Aaltonen, O., NÄÄTÄnen, R. (1998) Maturation of mismatch negativity in infants. International Journal of Psychophysiology, 2, 217-226.

Cheour-luhtanen, M., Alho, K., Kujala, T., Sainio, K., Reinikainen, K., Renlund, M., Aaltonen, O., Eerola, O., NÄÄTÄNen, R. (1995) Mismatch negativity indicates vowel discrimination in newborns. Hearing Research, 1, 53-58.

Chi, J. G., Dooling, E. C., Gilles, F. H. (1977) Left-right asymmetries of the temporal speech areas of the human fetus. Archives of Neurology, 6, 346-348.

Creutzfeldt, O., OJemann, G., Lettich, E. (1989) Neuronal activity in the human lateral temporal lobe. I. Responses to speech. Experimentak Brain Research, 3, 451-475.

CSÉPE, V. (1995) On the origin and development of mismatch negativity (invited review). Ear and Hearing, Special Issue: Mismatch Negativity as an Index of Central Auditory Function, $1,90-104$.

Csépe, V., Dieckman, B., Hoke, M., Ross, B. (1992) Mismatch negativity to pitch change of acoustic stimuli in pre-school and school-age children. Proceeding of the $10^{\text {th }}$ EPIC, Eger, Hungary, 32.

CsÉPE, V., Molnár, M. (1997) Towards the clinical application of the mismatch negativity evoked potential component. Audiology and Neuro-Otology, 2, 354-369.

Csépe, V., Osman-Sági, J., Molnár, M. (1998) Similarities and differences of deficient phoneme processing in aphasia and dyslexia. In Stalberg, E. V., De Weerd, A. W., Zidar, J. (eds) Clinical Neurophysiology. 549-555. Monduzzi Editore, Bologna

De Gelder, B., Vroomen, J. (1991) Phonological deficits: Beneath the surface of reading acquisition. Psychological Research, 53, 88-97.

Eimas, P. D., Miller, J. L. (1980) Contexual effects in infant speech perception. Science, 209(4461), 1140-1141.

Eimas, P. D., Siqueland, E. R., Jusczyk, P. W., Vigorito, J. (1971) Speech perception in early infancy. Science, 171, 304-306.

Elbro, C. (1996) Early linguistic abilities and reading development: A review and a hypothesis. Reading and Writing, 8, 453-485.

ELLiotT L. L. (1986) Discrimination and response bias for CV syllables differing in voice onset time among children and adults. Journal of the Acoustic Society of America, 4, 1250 1255 .

Elliott L. L., Hammer, M. A., Scholl, M. E. (1989) Fine-grained auditory discrimination in normal children and children with language-learning problems. Journal of Speech and Hearing Research, 32, 112-119.

Elliott, L. L., Longinotti, C., Meyer, D., RaZ, I., Zucker, K. (1981) Developmental differences in identifying and discriminating CV syllables. Journal of the Acoustic Society of America, 70, 669-677. 
Giard, M. H., Perrin, F., Pernier, J., Bouchet, P. (1990) Brain generators implicated in the processing of auditory stimulus deviance: a topographic event-related potential study. Psychophysiology, 27, 627-640.

Goswami, U., Bryant, P. (1990) Phonological Skills and Learning to Read. Lawrence Erlbaum, Hillsdale

Kerschner, J., Micallef, J. (1992) Consonant-vowel lateralization in dyslexic children: deficit or compensatory development? Brain Lang, 1, 66-82.

KORPILAHTI, P., LANG, H. A. (1994) Auditory ERP components and mismatch negativity in dysphasic children. Electroencephalography and Clinical Neurophysiology, 4, 256-264.

Kraus, N., Koch, D. B., McGee, T. J., Nicol, T. G., Cunnigham, J. (1999) Speech-sound discrimination in school-age children: psychophysiological and neurophysiologic measures. Journal of Speech Language and Hearing Research, 5, 1042-1060.

Kraus, N., McGee, T. J., Carrell, T. D., King, C., Littman, T., Nicol, T. (1994) Discrimination of speech-like contrasts in the auditory thalamus and cortex. Journal of the Acoustic Society of America, 5, 2758-2768.

Kraus, N., McGee, T. J., Carrell, T. D., Sharma, A. (1995) Neurophysiologic bases of speech discrimination. Ear and Hearing, 1, 19-37.

Kraus, N., McGee, T. J., Carrell, T. D., Sharma, A., Micco, A., Nicol, T. (1993) Speechevoked cortical potentials in children. Journal of the American Academy of Audiology, 4, 238-248.

Kraus, N., McGee, T. J., Carrell, T. D., Zecker, S. G., Nicol, T. G., Koch, D. B. (1996) Auditory neurophysiologic responses and discrimination deficits in children with learning problems. Science, 273, 971-973.

Kraus, N., McGee, T. J., Sharma, A., Carrell, T. D., Nicol, T. (1992) Mismatch negativity eventrelated potential elicited by speech stimuli. Ear and Hearing, 3, 158-164.

Kurtzberg, D., Vaughan, H. G., Kreuzer, J. A., Fliegler, K. Z. (1995) Developmental studies and clinical application of mismatch negativity: problems and prospects. Ear and Hearing, 1, 115-117.

Leppänen, P. H., Lyytinen, H.: (1997) Auditory event-related potentials in the study of developmental language related disorders. In Csépe, V., Näätänen, R. (eds) Evoked and event-related potentials in hearing research and clinical application. Special Issue of the Audiology and Neurootology. 308-340. Karger, Basel

McBride-Chang, C. (1995) Phonological processing, speech perception, and reading disabiliy, Integrative review. Journal of Educational Psychology, 30, 109-121.

McKeever, W. F., Van Deventer, A. D. (1975) Dyslexic adolescents: evidence of impaired visual and auditory language processing associated with normal lateralization and visual responsivity. Cortex, 4, 361-378.

Molfese, D. L. (1978) Left and right hemisphere involvement in speech perception: electrophysiological correlates. Percept Psychophys, 3, 237-243.

Molfese, D. L. (1980) The phoneme and the engram: electrophysiological evidence for the acoustic invariant in stop consonants. Brain Lang, 2, 372-376.

Molfese, D. L., Linnville, S. E., Wetzel, W. F., Leicht, D. (1985) Electrophysiologycal correlates of handedness and speech perception contrasts. Neuropsychologia, 1, 77-86.

Molfese, D. L., Schmidt, A. (1983) An auditory evoked potential study of consonant perception in different vowel environments. Brain Lang, 1, 57-70. 
Morais, J., Alegria, J., Content, A. (1987) The relationship between segmental analysis and literacy: An interactive view. Cahiers de Psychologie Cognitive, 7, 415-438.

Ohde, R. N., Haley, K. L., McMahon, C. V., (1996) A developmental study of vowel perception from brief synthetic consonant-vowel syllables: Journal of Acoustical Society of America, 6, 3813-3824.

Olson, R., Wise, B., Connors, F., Rack, J. (1990) Organisation, heritability and remediation of component word recognition and language skills in disabled readers. In Carr, T., Levy, B. A. (eds) Reading and its Development: Component Skills Approaches. Academic, San Diego

Oyama, S. (1976) A sensitive period for the acquisition of a non-native phonological system. Journal of Psycholinguistic Research, 5, 261-285.

Pinkerton, F., Watson, D. R., McClelland, R. J. (1989) A neurophysiological study of children with reading, writing and spelling difficulties. Developmental Medicine and Child Neurology, 31, 569-581.

REeD, M. A. (1989) Speech perception and the discrimination of brief auditory cues in reading disabled children. Journal of Experimental Child Psychology, 48, 270-292.

Schulte-Körne, G., Deimel, W., Battling, J., Remschmidt, H. (1998) Auditory processing and dislexia: evidence for a specific speech processing deficit. Neuroreport, 26;9(2), 337-340.

Shafer, V. L., Morr, M. L., Kreuzer, J. A., Kurtzberg, D. (2000) Maturation of mismatch negativity in school-age children. Ear and Hearing, 21, 242-251.

SHARE, D. (1995) Phonological recoding and self-teaching: Sine qua non of reading. Cognition, 55, 151-218.

Sharma, A., Kraus, N., McGee, T. J., Nicol, T. G. (1997) Developmental changes in P1 and N1 central auditory responses elicited by consonant-vowel syllables. Journal of Electroencephalography and Clinical Neurophysiology, 104, 540-545.

Shaywitz, S. E., Fletcher, J. M., Holahan, J. M., Shneider, A. E., Marchione, K. E., Stuebing, K. K., Francis, D. J., Pugh, K. R., Shaywitz, B. A. (1999) Persistence of dyslexia: the Connecticut Longitudinal Study at adolescence. Pediatrics, 6, 1351-1359.

SNOWLInG, M. (1980) Development of grapheme-phoneme correspondence in normal and dyslexic readers. Journal of Experimental Child Psychology, 29, 294-305.

Stanovich, K. E., Siegel, L. S. (1994) Phenotipic performance profile of children with reading disabilities. A regression-based test of the phonological-core variable-difference model. Journal of Educational Psychology, 86, 24-53.

Stein, J. F., McAnally, K. (1995) Auditory temporal processing in developmental dyslexics. Irish Journal of Psychology, 16, 220-228.

Stein, L., Kraus, N., McGee, T. J., Koch, D. B. (1995) New developments in the clinical application of auditory evoked potentials with children with multiple handicaps. Scandinavian Audiology, 41, 18-30.

Studdert-Kennedy, M., Mody, M. (1995) Auditory temporal perception deficits in the reading-impaired: A critical review of the evidence. Psychonomic Bulletin Review, 2, 508514.

Sussman, J. E. (1993a) Auditory processing in children's speech perception: Results of selective adaptation and discrimination tasks. Journal of speech and Hearing Research, 2, 380-395. 
Sussman, J. E. (1993b) Perception of formant transition cues to place articulation in children with language impairments. Journal of speech and Hearing Research, 6, 1286-1299.

TAllal, P. (1980) Auditory temporal perception phonics and reading disability m children. Brain and Language, 9, 182-198.

Tallal, P., Miller, S., Bedi, G., Byma, G., Wang, X., Nagarajan, S., Schreiner, C., Jenkins, W., Merzenich, M. (1996) Language comprehension in language-learning impaired children improved with acoustically modified speech. Science, 271, 81-84.

TAllal, P., Miller, S., Fitch, R. H. (1993) Neurobiological basis of speech: a case for the preeminence of temporal processing. In Tallal, P., Galaburda, A. M., Llinás, R. R., von Euler, C. (eds) Temporal information processing in the nervous system. Special reference to dyslexia and dysphasia. Annals of the New York Academy of Sciences, 682, 27-47.

Torgeson, J. K., MATHES, P. (1999) What every teacher should know about phonological awareness. In: Reading Research: Anthology: The why? of reading instruction. 54-61. Arena Press, Novato

Tremblay, K., Kraus, N., Carrel, T. D., McGee, T. (1997) Central auditory system plasticity: generalization to novel stimuli following listening training. Journal of Acoustic Society of America, 6, 3762-3773.

Tremblay, K., Kraus, N., McGee, T. (1998) The time course of auditory perceptual learning: neurophysiological changes during speech-sound training. Neuroreport, 16, $3557-3560$.

Wimmer, H., Goswami, U. (1994) The influence of orthographic consistency on reading development Word recognition in English and German Children. Cognition, 51, 91103.

Winkler L., Lehtokoski A., Alku, P., Vainio, M., Czigler, I., Csepe, V., Aaltonen, O., Raimo, L., Alho, K., Lang, H., IIvonen, A., NÄÄTÄnen, R. (1997) Pre-attentive detection of vowel contrasts utilises both phonetic and auditory memory representations. Cogninitve Brain Research, 3, 357-369.

Wood, F., Flowers, L., Buchsbaum, M., Tallal, P. (1991) Investigation of abnormal left temporal functioning in dyslexia through $\mathrm{rCBF}$, auditory evoked potentials and positron emission tomography. Reading and Writing, 3, 379-393.

\title{
ABNORMAL MISMATCH NEGATIVITY TO PHONETIC DEVIATIONS IN DEVELOPMENTAL DYSLEXIA
}

\author{
CSÉPE, VALÉRIA-SZŰCS, DÉNES-OSMAN SÁGI, JUDIT
}

Developmental dyslexia, more commonly known as reading disorder, is a specific disability in learning to read and in most cases persists throughout life. In the past decade empirical evidence has accumulated to suggest that both visual and acoustic processing may be disturbed in dyslexia. The aim of the present study was to assess whether dyslexic children can be separated from controls of a high variability of acoustic and phonetic discrimination performance by measuring the mismatch negativity component 
of event related potentials. The MMN elicited by pitch, vowel and consonant-vowel (CV) contrasts was measured in dyslexics of 9 years of age and in two groups of age matched controls. The most reliable $M M N$ differences between dyslexics and controls were found in the CV condition where voicing and place of articulation were used as contrasting features. Furthermore, the MMN to CV contrasts was revealed to be different in comparison with the subgroup of controls separated according to their poor phoneme discrimination performance. Our MMN results suggest that the speech sound representation of developmental dyslexics and children of developmental lag is different.

Key words: developmental dyslexia, developmental lag, acoustic and phonetic processing, mismatch negativity, event-related potentials, speech-sound discrimination 